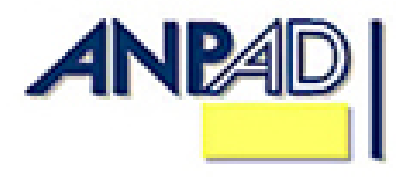

Available online at

http://www.anpad.org.br/bar

BAR, Rio de Janeiro, v. 11, n. 3, art. 1, pp. 248-263, July/Sept. 2014

\title{
Consumer Complaints and Company Market Value
}

Danny Pimentel Claro

E-mail address: danny@insper.edu.br

Insper Instituto de Ensino e Pesquisa

Insper, Rua Quatá, 300, 04546-042, São Paulo, SP, Brazil.

Antonio Fabio Guena Reali Fragoso

E-mail address: antoniofgrf@al.insper.edu.br

Insper Instituto de Ensino e Pesquisa

Insper, Rua Quatá, 300, 04546-042, São Paulo, SP, Brazil.

Silvio Abrahão Laban Neto

E-mail address: silvioaln@insper.edu.br

Insper Instituto de Ensino e Pesquisa

Insper, Rua Quatá, 300, 04546-042, São Paulo, SP, Brazil.

Priscila Borin de Oliveira Claro

E-mail address: priscila.claro@insper.edu.br

Insper Instituto de Ensino e Pesquisa

Insper, Rua Quatá, 300, 04546-042, São Paulo, SP, Brazil.

Received 23 July 2013; received in revised form $2^{\text {nd }}$ April 2014 (this paper has been with the authors for two revisions); accepted $2^{\text {nd }}$ April 2014; published online $1^{\text {st }}$ July 2014.

Editor's note. Claude Obadia served as Associate Editor for this article 


\begin{abstract}
Consumer complaints affect company market value and common sense suggests that a negative impact is expected. However, do complaints always negatively impact company market value? We hypothesize in this study that complaints may have a non-linear effect on market value. Positive (e.g. avoiding high costs to solve complaints) and negative (e.g. speedy and intense diffusion) tradeoffs may occur given the level of complaints. To test our non-linear hypothesis, a panel data was collected from cell phone service providers from 2005 to 2013. The results supported our tradeoff rationale. Low levels of complaints allow for companies to increase market value, while high levels of complaints cause increasing harm to market value. The sample, model and period considered in this study, indicates a level of 0.49 complaints per thousand consumers as the threshold for a shift in tradeoffs. The effects on market value become increasingly negative when trying to make reductions to move below this level, due to negative tradeoffs.
\end{abstract}

Key words: consumer complaints; negative word of mouth; satisfaction; company market value; communication. 


\section{Introduction}

Managers have closely monitored consumer complaints to further develop marketing programs and manage customer dissatisfaction. Previous studies showed that dissatisfaction may result in negative word of mouth, for instance by people warning friends (Matos \& Rossi, 2008; Singh \& Wilkes, 1996; Trusov, Bucklin, \& Pauwels, 2009), or may result in complaints to private or public agencies (Singh, 1988). Consumers play a critical role in spreading brand value and affecting the efficiency of marketing programs (Kozinets, Valck, Wojnick, \& Wilner, 2010). Consumers have also gained control over a wide variety of media available to them, including posting opinions online and having the option to block unsolicited marketing (De Bruyn \& Lilien, 2008).

In some public service industries, regulatory agencies keep public records of complaints and assess companies' performance on the basis of consumer complaint levels. Public records of complaints also affect market perception about a company and help disseminate failure of products and services by simply describing stories of negative experiences (Luo, 2009; Winchester, Romaniuk, \& Bogomolova, 2008). Very often in a complaining context, the informant is not necessarily an opinion leader with his/her reputation at stake (Weimann, 1991). Rather, emotions are evident and the story of the informant deeply touches listeners (Richins, 1983) in such a way that evoke a good and evil battle or a perception of a seriously harmed victim (Laer \& Ruyter, 2012). The company then becomes vulnerable to the level of complaint that influences the company market value in a direct linear fashion (Luo, 2007, 2009) or in a novel, non-linear way.

We hypothesize in this study that complaints may have a non-linear effect on company market value. The hypothesis deals with a company's ambition to defeat consumer complaint at any cost. We actually expect positive and negative tradeoffs between complaint and performance, suggesting that a company may have market value increased with low levels of complaints. Once a certain level of complaint is displayed, further increase in complaints will sharply reduce company market value. We argue that positive tradeoffs (i.e. market value increase under increasing complaint levels) create conditions for companies to avoid image decay and save costs by not attending to over-demanding consumers and costly problem-solving issues. We also argue that negative tradeoffs (i.e. market value decrease under increasing levels of complaints) destroy corporate and brand reputation as well as increase the speed and intensity of bad evaluation diffusion.

Previous studies looked deeply into the behavior and antecedents of complaints (Richins, 1983; Singh \& Wilkes, 1996), and the direct linear effect on company market value (Chevalier \& Mayzlin, 2006; Goldenberg, Libai, Moldovan, \& Muller, 2007; Mittal, Ross, \& Baldasare, 1998; Romani, Grappi, \& Dalli, 2012). Beyond these previous contributions, our paper contributes to the literature by suggesting a non-linear effect of complaints on a company's market value. Intuitively, it seems evident that high levels of complaints are associated with poor financial performance, however, marketing research has mainly paid attention to the effects on customer experiences, especially at the customer satisfaction levels (Bernhardt, Donthu, \& Kennett, 2000; Fornell, Mithas, Morgeson, \& Krishnan, 2006; Luo \& Homburg, 2008). In addition, studies have focused more on assessing consumer intentions (East, Hammond, \& Lomax, 2008) or employee satisfaction (Bernhardt et al., 2000) and few have measured companies' financial performance (see Torres \& Tribó, 2011 for one exception).

There has been a need to establish better metrics to measure how different marketing strategies affect a company's market value (Mintz \& Currim, 2013; Srinivasan \& Hanssens, 2009) and a growing trend has arisen where financial indicators are increasingly being applied to previous studies (Anderson, Fornell, \& Mazvancheryl, 2004; Fang, Palmatier, \& Steenkamp, 2008; Goldenberg et al., 2007; Luo \& Homburg, 2008; Osinga, Leeflang, Srinivasan, \& Wieringa, 2011). Lehman (2004) emphasizes that practitioners who want to be involved in the important decisions their businesses make should seek consistent links between strategies and financial indicators, in particular, those related to increasing shareholder value. Studies have used Tobin's Q Ratio as a parameter to calculate a company's market value and as a metric to evaluate the effectiveness of strategies (e.g. Fang et al., 
2008). Therefore, the aim of our study is to explore the impact of a non-linear effect of complaint on company market value as measured by its Tobin's $\mathrm{Q}$.

The empirical evidence to test our hypothesis was obtained from panel data collected from 2005 to 2013, from ANATEL, the regulatory agency that deals with all telecommunication issues in Brazil. ANATEL's website provides monthly data on the number of complaints made to the agency, broken down by cell phone service provider, since 2005 . Complaints made to a third party agency is critical for a company's performance because consumers may have already complained directly to the company and to others (Cronin \& Fox, 2010; Ruyter \& Brack, 1993). We also collected data from the three main publicly quoted cell phone service providers in Brazil. These three cell phone providers that compose the data for the empirical test account for $72 \%$ of the market and were chosen due to their large client base and high number of complaints according to ANATEL records. Over 750,000 complaints related to these companies have been reported to ANATEL. This industry is also suitable for our study because of the highly competitive market and the relatively homogeneous products, which provide a context for negative consumer opinion to become relevant to distinguish one company brand from another. This context, resembling a homogeneous oligopoly market structure, has been theoretically shown to be an interesting setting to study complaint issues (Fornell \& Wernerfelt, 1988). Finally, previous academic studies have focused mainly on the Northern Hemisphere context, especially the United States (S. W. Brown et al., 2005). Our study also adds to the literature by looking at the complaint issue in specific markets and in a developing country. The following sections will summarize the theory relevant to this research, the methods used, an analysis of the data, and a discussion of our results and conclusions.

\section{Consumer Complaint and Company Market Value}

There is a growing consensus that market value better captures the impact of consumer complaints (Luo, 2009; Luo \& Homburg, 2008). Immediately after receiving bad service, consumers can, for instance, pass on a negative comment about the service by phone, in person or through online social networks (Bentivegna, 2002; Santos \& Fernandes, 2011). Consumers tend to make great efforts to pass on the details of serious problems (Richins, 1983). Not all word of mouth is equal, and it depends on the proximity of the source to those involved, the source's influence and credibility and the characteristics of the network where the word of mouth is occurring (J. J. Brown \& Reingen, 1987). A third party agency's credentials may further intensify the impact of complaints by simply collecting, sorting, and disseminating the issues to the general public (Ruyter \& Brack, 1993). Depending on the agency's or consumer's influence in a given industry, there may be severe damage to the company's reputation and eventually to its sales. Complaints can give the company a chance to compensate for bad service or recover a lost sale, once the problem is properly identified and consumer trust is redeemed (Santos \& Fernandes, 2008).

A seminal study on the nature of consumer dissatisfaction showed three dimensions by which consumers respond to a bad experience with a product or service (Singh, 1988). First, consumers may engage in voice response by seeking to redress the problem directly with the company. Consumers may want to have the product repaired or other compensation. Second, telling friends and relatives about the problem is also regarded as a dimension of customer dissatisfaction response. This negative word of mouth creates a remedy arousal that feeds back into future actions. Third, the response may also be materialized by filing a formal complaint report with a third party public or private agency. Reporting to agencies is considered a voluntary hard action while the other two response dimensions are considered easy choices (Singh \& Wilkes, 1996). Feick (1987) posited that third-party responses are at a higher hierarchical level than voice and private, negative word of mouth. Furthermore, previous empirical studies have shown that when third-party responses happened it is because any kind of voice or negative word of mouth has happened before (Singh \& Wilkes, 1996). Agency reports are objective and not driven by consumer intention to complain since it captures the actual fact that 
consumers have formally complained. Therefore, we isolate the third-party influence and focus on the impact of public records of complaints to assess the impact on company market value.

A common mistake made by managers is to not adequately measure financial results of their marketing programs, which undermines their overall company credibility (Mintz \& Currim, 2013; Rust, Lemon, \& Zeithmal, 2004). There is a relationship between customer satisfaction and generating shareholder value, which underlines the relevance of market value (Anderson et al., 2004; Gruca \& Rego, 2005; Luo \& Homburg, 2008). Several studies seek to establish empirical evidence about the impact of marketing activity on company financial indicators (e.g. Anderson et al., 2004; Sorescu \& Spanjol, 2008). The underlying logic considers that customer satisfaction positively influences a company's ability to retain them, and this guarantees future revenue and reduces the cost of future transactions, such as investments in advertising, services and sales (Anderson et al., 2004).

One of the ways to evaluate the impact of marketing strategies on company market value is to use Tobin's Q Ratio. This is an index based on share values, which presents advantages over traditional financial indices such as Return on Assets or Return on Net Capital (Fama, 1970). The Tobin's Q, based on the theory of efficient market prices, reflects all available relevant information including projected future cash flow adjusted for risk, and reflecting a company's intangible assets, which cannot easily be measured by accounting figures (Srivastava, Shervani, \& Fahey, 1998). The Q ratio is used to compare companies in different industries, because it is not affected by specific accounting conventions (Chakravarthy, 1986).

\section{The Non-Linear Effect of Complaints}

Previous literature and evidence indicates that complaints reduce company performance, though we argue that the level of complaints present an inverted U-shape effect on performance. Luo (2007) suggests that achieving $100 \%$ customer satisfaction is not a very realistic scenario and is rarely viable. There may be diminishing returns in efforts to satisfy customers (Dixon, Freeman, \& Toman, 2010). An increase in complaint level can reduce company market value, however not necessarily every time. This is because the cost, time, quality, technological restrictions and customer satisfaction establish limits as to what can be achieved, making it necessary for managers to make choices as tradeoffs emerge (Skinner, 1969). The tradeoff concept requires that companies, when working close to the limit of their resources, make choices between their competitive priorities. We therefore expect positive and negative tradeoffs regarding complaint level effect on market value (Figure 1).

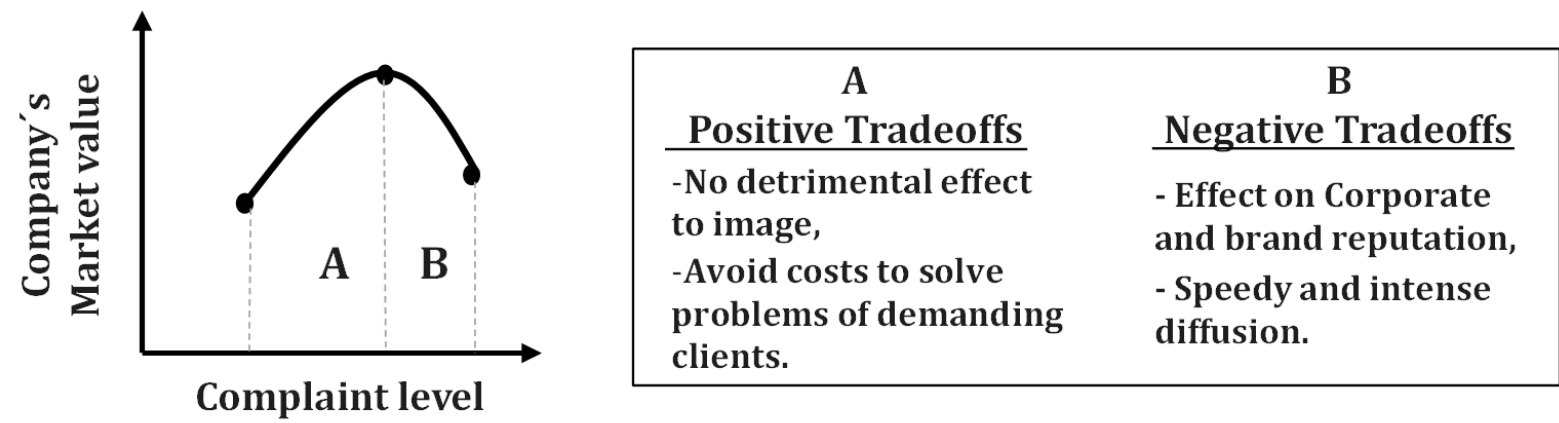

Figure 1. Model of the Non-linear Effect of Complaints on a Company's Market Value.

Positive tradeoffs may emerge and generate an increase in market value even under a low level of complaint. Two mechanisms may underlie such an increase. First, market value increase is possible because company image is little exposed to severe damage. Consumers holding emotional bonds with a company may tolerate other consumers' bad experiences and rationalize it as less problematic personally. Even calculative consumers find no reason to stop buying from a seller and are not willing to afford the switching costs to move to a new seller (R. Lee \& Romaniuk, 2009). From the stock 
market perspective, as long as consumers are willing to continue buying from a company, there is no negative effect on market analyst reports and consequently on stock prices. This allows for the company to even increase its market value under a low level of complaints.

The second mechanism to operate in positive tradeoffs is a company's cost reduction rationale that surpasses the benefits of reducing the overall damage of a low complaint level. First, neglecting certain complaints may be justified by the high costs of solving the root of a problem. Companies often worry just about measuring customer satisfaction and forget to assess the customer lifetime value (CLV). The CLV allows for an accurate evaluation over time whether a client provided revenues that exceed, by an adequate margin, the marketing, sales and customer service costs spent in relation to this particular customer (P. D. Berger et al., 2006; Venkatesan \& Kumar, 2004). Considering how heterogeneous individuals are, managing negative word of mouth of complaints will be efficient when it is possible to attract and retain customers who offer high potential profitability (Niraj, Grupta, \& Narasimhan, 2001). It is often necessary to address each customer's specific complaints to reduce negative word of mouth. Based on the concept of tradeoffs and client profitability, reducing negative word of mouth that are already at low levels can mean significant increases in costs, due mainly to the high level of personalization or customization of services, which can compromise a company's profitability and consequently its market value.

Second, neglecting extremely demanding customers may be justified by the high costs of satisfying them. An increase in complaint level can originate from a base of consumers who offer little potential profitability and became dissatisfied due to a price increase or simply reducing the package of services and customizations available (Niraj et al., 2001). Complaints may emerge when customer satisfaction is dependent on product or service customization. Anderson, Fornell and Rust (1997) argue that there is incompatibility between customer satisfaction and company market value when it is costly to provide high levels of customization. Under these circumstances, an increase in complaint level may not necessarily be harmful to company market value, given the savings generated by not fulfilling the specific needs of these customers. In the effort to reduce significant negative effects, it is important to verify whether the company, in promoting products and services, has not created excessive expectations that will lead to future dissatisfaction (Osinga et al., 2011). Consumers perceive the product value on the basis of what the company's promises are, thereby seeking satisfaction over the long term.

Negative tradeoffs, on the other hand, follow a stream of research that focuses on the motives that lead consumers to make their voice loud and spread their bad experience. Very satisfied or very dissatisfied customers are more likely to initiate positive or negative word of mouth (Anderson, 1998; Matos \& Rossi, 2008). Previous studies, based on psychological aspects, begin with a companies' mistakes and investigate how they cause consumers' negative emotions, which are antecedents to dissatisfaction responses (Romani et al., 2012; Sjödin, 2008). In Dixon, Freeman and Toman (2010), just $23 \%$ of customers who had a positive experience related to a product or service sent this information to 10 or more people. On the other hand, $48 \%$ of customers who had a negative experience sent this information to 10 or more people. Heskett, Jones, Loveman, Sasser and Schlesinger (1994) developed the concept of the terrorist customer who can significantly affect a company's profitability. This type of customer is so dissatisfied with the quality of a service provided that she spreads negative information whenever the opportunity arises and is able to reach hundreds of other potential customers through the internet (Santos \& Fernandes, 2011).

Two mechanisms underlie the negative tradeoff. First, corporate and brand reputation - i.e. defined by how consumers perceive a company or a brand - affect company's market value (Grönroos, 1984). There is a negative consumer reaction when the company or its employees deliver a poor service or product (Harris \& Ogbonna, 2013; McColl-Kennedy, Sparks, \& Nguyen, 2011; Santos $\&$ Fernandes, 2008). Consumers that receive any negative information from a third-party source about a product or service tend to have lower attitudes towards the company, especially when compared to those receiving no information at all (Matos \& Veiga, 2005). A brand with a high number of complaints indicates a low level of satisfaction with a company's offering, diminishing the capacity to attract and retain customers and consequently, impacting the company's future expected cash flow 
(Luo, 2007). By raising their client retention level by $1 \%$, a company is able to increase market value by 3\% to 7\% (Gupta, Lehman, \& Stuart, 2004). Also, the customer base and their level of satisfaction may be considered as a company's intangible assets (Rust et al., 2004).

Complaints damage intangible assets, because they increase the costs of attracting and retaining customers (Anderson et al., 2004), and also diminish a company's ability to maintain revenue and garner repeat consumers (Luo, 2007), reducing customer tolerance toward price increases (Chevalier \& Mayzlin, 2006). Complaints also increase the risks associated with future cash flow. Positive customer satisfaction gives companies greater protection from external shocks and/or competitor maneuvers reducing cash flow loss (Gruca \& Rego, 2005). Such positive effects reduce a company's cost of capital. Smith, Smith and Kun (2010) and Andreassen and Lindestad (1998) found that reputation is positively correlated with satisfaction and brand loyalty. A company's market value may be damaged by a high complaint level.

Second, the mechanism of negative tradeoffs is also associated with a speedy and intense diffusion over the social networks. There has been a rapid spread of broadband internet connections and a proliferation of blogs, interactive websites and multiuse cell phones (Santos \& Fernandes, 2011). The negative response of a bad experience intensifies and spreads quickly over this high level of interconnectedness among consumers (Goldenberg et al., 2009). This interconnectedness allows consumers to exert a growing influence on brand reputation. In the past, consumers expressed their perceptions of brands by talking with friends or relatives; nowadays consumers use internet sites to disseminate their positive and negative experiences (Ward \& Ostron, 2006). Consumers also have control over the wide variety of media available, including the option to act as an online referral (De Bruyn \& Lilien, 2008). They are prone to accept information about a brand when the origin is another consumer that might be friend or an unbiased informant, and consequently are likely to accept information about the product (Dichter, 1966).

The central hypothesis of our study thus posits a non-linear effect of complaints on a company's market value. Low levels of complaints are positive for a company's market value because of the positive tradeoffs. Not incurring costs and investments necessary to further reduce these levels compensate for the impact of complaints. However after a certain level, as complaints increase and are increasingly and more rapidly spread, there are greater negative effects on customer satisfaction and loyalty as well as reputation and brand value, reducing future cash flow and increasing cash-flow risk. Thus, we can enunciate the central hypothesis of our study:

Hypothesis: Complaints have a negative, non-linear effect on company market value: at low levels, positive tradeoffs occur which increase a company's market value and as complaint grows beyond a critical level, its effect on company market value becomes increasingly negative.

\section{Method}

We collected data from cell phone service providers in Brazil. The cell phone market reached 136 phones per 100 inhabitant in December 2013 and has doubled in size over the past five years according to ANATEL (the National Telecommunication Regulatory Agency). Quarterly data from $1 \mathrm{Q} / 2005$ to $2 \mathrm{Q} / 2013$ was collected from the three leaders in the cell phone industry, giving a total sample size of 102 measurements. Another cell phone service provider that operates in this market could not be included in this study because its headquarters is overseas and the financial data for the local operation is not publicly available. According to ANATEL, the three selected companies at the end of 2013 represented $72.4 \%$ of the Brazilian market, which provides an interesting setting to study complaints. 


\section{Study variables}

The dependent variable for the company market value was estimated based on Tobin's Q Ratio. This Q Ratio has been used in marketing literature in studies related to brand equity (Simon \& Sullivan, 1993), service evaluation (Fang et al., 2008) and customer satisfaction (Anderson et al., 2004). We followed the method proposed by Chung and Pruitt (1994) to calculate the ratio. Formally, we measure Tobin's Q Ratio as follows:

$$
\mathrm{Q}=\frac{\text { (Share Market Price }+ \text { Liabilities) }}{\text { Total Asset Value }}
$$

where total asset value and liabilities are drawn from the balance sheet of the company. The share market price at a determined moment in time is an important component of the formula. To reduce the volatility of a single measurement of share price, R. P. Lee and Grewal (2004) recommend that the average share price of previous periods be used at the time that Tobin's Q Ratio is calculated. In our study we used a quarterly average, where the average is the closing price for each month within the quarter based on the historical data drawn from BM\&F Bovespa (the Brazilian Stock Market).

Complaints were collected and analyzed according to Singh's protocol (1988). Singh and Wilkes (1996) found evidence that complaints to third parties are a solid objective measure because it comes after any kind of previous complaint to either the company or family and friends. Previous study has employed complaints to third parties as a measure to study consumer dissatisfaction (Ruyter \& Brack, 1993). The complaint type made to a regulatory agency denotes a serious issue and high degree of frustration with the bad experience with the product or service (Cronin \& Fox, 2010). We draw from the ANATEL records to compute the independent variable, which account for the relative number of complaints for each company in the given quarter. The complaint variable also accounts for possible differences in complaint volume due to customer base size. For the non-linear effect of complaint we employed a squared variable.

According to Shaver (1998), to capture the effects of a particular variable on company performance it is important to include control variables. Companies eventually face random errors when making decisions. We therefore included three control variables that affect a company's performance. The first is the level of financial debt or leverage, which has been used in various studies related to corporate finance (P. G. Berger \& Ofek, 1995). A company's total debt divided by the value of all of its shares is used as a measurement of a company's debt situation. The second is the stock market index that considers the variation in return offered by this segment of the market which in turn is reflected in stock prices. This index also reflects any variations in country risk as well as risk free levels that can also affect stock prices. The Ibovespa Index is included as a control, because it is the most important average performance indicator for stocks on the Brazilian stock market. The third is the customer base size which was considered a control variable for company size. Some previous studies that used Tobin's Q Ratio also used company size as a control variable (Fang et al., 2008; Sorescu \& Spanjol, 2008).

\section{Results}

The model estimation followed the balanced panel structure of our data that contains time series of observations for three companies in a multiple, cross-sectional method. This requires attention to several estimation issues (Gujarati, 2003). First, serial correlation of Tobin's Q can be problematic because it may bias parameter estimates. In our sample, a panel Durbin-Watson statistic was calculated for the panel data and no significant autocorrelation was observed $(\mathrm{p}<0.05)$. To control for any unobserved firm heterogeneity, we included control variables that account for firm-specific effects in the model. Second, we conducted a Hausman specification test and found it significant (1.28, 
$\mathrm{p}<0.05$ ), which indicates that a random effects treatment of unobserved heterogeneity is not tenable. This test assessed non-observed effects that are related to factors intrinsic to the cross-sectional method, which may vary over time. These effects may include each company's management model, management ability or cultural aspects. The Hausman test allow us to consider that these non-observed variables do not affect the dependent variable under analysis. Therefore, we adopt the two-way, fixedeffects panel regression model that allows using within group (i.e. companies) regression estimators.

Consistent with our central hypothesis, we specify a quadratic parameter of complaint to assess the non-linear impact on company market value. We expect that complaints begin to decrease market value only after a critical level, and thus we anticipate that the linear effect will be significantly positive and that the quadratic effect will be significantly negative. If both effects are negative, complaints decrease market value at all levels of complaints. Table 1 presents the results obtained for the proposed model, where Tobin's Q Ratio is a dependent variable and complaint is the independent variable. The quadratic variable and the control variables are also included. Residual plots of the estimation presented a random pattern as expected.

The results confirm the proposed central hypothesis. The significant negative effect of the square of the complaint variable $(\beta=-1.08 ; \mathrm{p}<0.01)$ indicates that the negative effects of complaints on company market value are not linear and do indeed decrease market value only when higher levels are reached. As expected, the significant positive result for the linear term $(\beta=1.39 ; p<0.01)$ indicates that at low levels the impact of an increase in complaint is positive for a company's market value.

Table 1

\section{Results of Statistical Analysis}

\begin{tabular}{lcccc}
\hline Dependent Variable: Tobin's Q & $\mathbf{b}$ & $\boldsymbol{\beta}$ & Std_Error & p-value \\
\hline Intercept & -1.18 & -0.00 & $(-1.05)$ & 0.112 \\
Complaints & $11.18^{* *}$ & $0.41^{* *}$ & $(-6.25)$ & 0.001 \\
(Complaints) $^{2}$ & $-11.49^{* *}$ & $-0.13^{* *}$ & $(-9.15)$ & 0.010 \\
Control Variables & & & & \\
Customer Base Size & $-0.01^{* *}$ & $-0.49^{* *}$ & $(-0.01)$ & 0.000 \\
Company's Leverage & $0.88^{*}$ & $0.17^{*}$ & $(-0.82)$ & 0.042 \\
Stock Market Index & $0.01^{* *}$ & $0.21^{* *}$ & $(-0.01)$ & 0.009 \\
$\mathrm{R}^{2}$ & 0.388 & & & \\
F-Statistics & $11.9^{* *}$ & & & \\
Degrees of Freedom & $(5,94)$ & & & \\
\hline
\end{tabular}

Note. $* \mathrm{p}<.05 ; * * \mathrm{p}<.01 . \beta$ : standardized coefficient.

All control variables present statistically significant results. For company size (their customer base), the coefficient sign was negative, contrary to the results of past research done in other contexts (Fang et al., 2008; Sorescu \& Spanjol, 2008). One might suggest that the high rate of market growth during the study period could have influenced the analysis. In order to meet the needs of an ever growing customer base in the cell phone service industry, constant investments in infrastructure are necessary to guarantee access to service provider networks for all customers (Fleury \& Fleury, 2003). Thus, the result of these investments is the fast growth in the assets of each of these companies which, according to the model proposed by Chung and Pruitt (1994), can negatively affect Tobin's Q Ratio when share prices do not accompany this same accelerated rhythm. Such issues may be addressed in future studies. The other control variables, company's leverage and stock market index, were positive as expected. 
Figure 2 illustrates the results in a scatter plot and a graph plotting complaints against company's market value (Tobin's Q Ratio) and shows the quadratic effect. The sample, model and period considered in this study indicates a break point of 0.49 complaints per thousand consumers in a company's customer base. The effects on market value become increasingly negative when trying to make reductions to move below this level due to the negative tradeoffs - in terms of company market value $v s$. complaints.

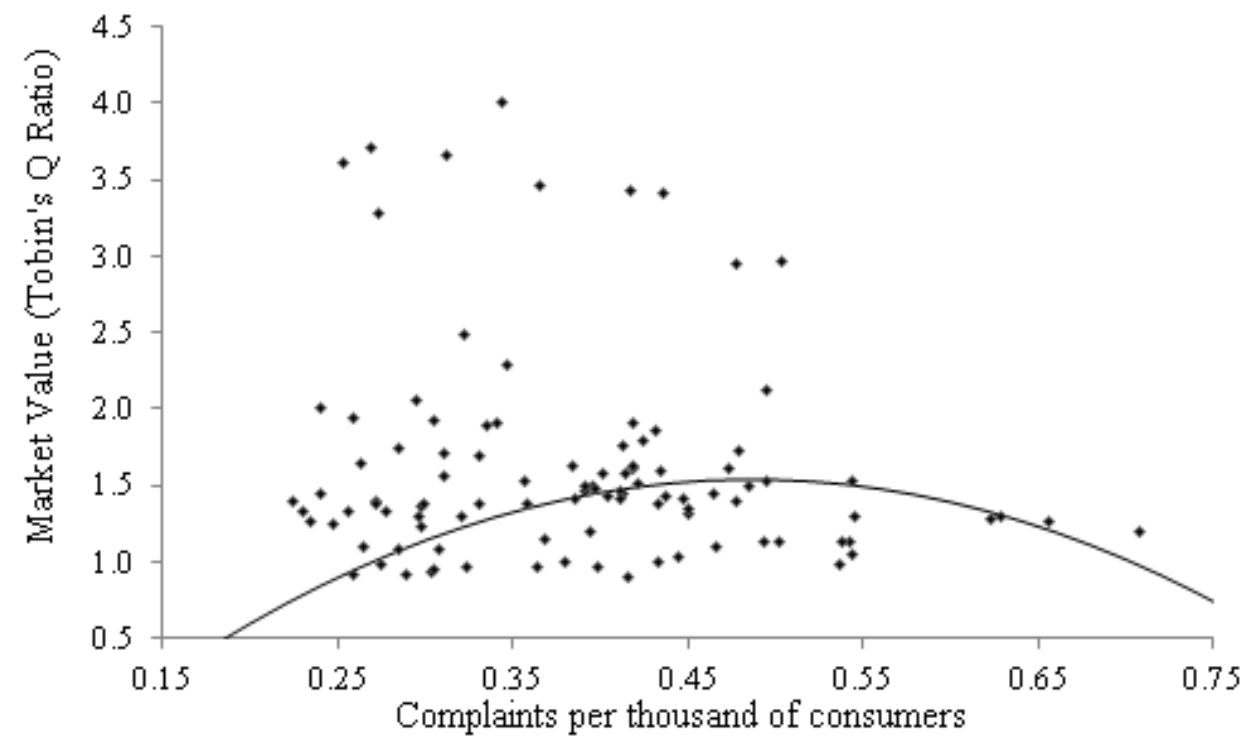

Figure 2. Scatter Plot and Estimated Function for Complaint Level and Company Market Value.

Figure 3 provides a descriptive analysis of the break point in our sample. Comparing the break point determined by the estimated coefficients of our study with the individual service provider data, we find that company B on average operated close to this break point level of complaints, indicating an effective way to manage this issue. Company $\mathrm{C}$, on the other hand, operated most of the time at levels below the threshold, suggesting, according to our model, idle capacity or excessive customization for the consumer, which can negatively affect market value. Finally company A, beginning in 2007, showed great variability in its complaint level and had relatively high points in relation to the estimated break point, indicating possible growing dissatisfaction with the brand's reputation and decreased customer loyalty.

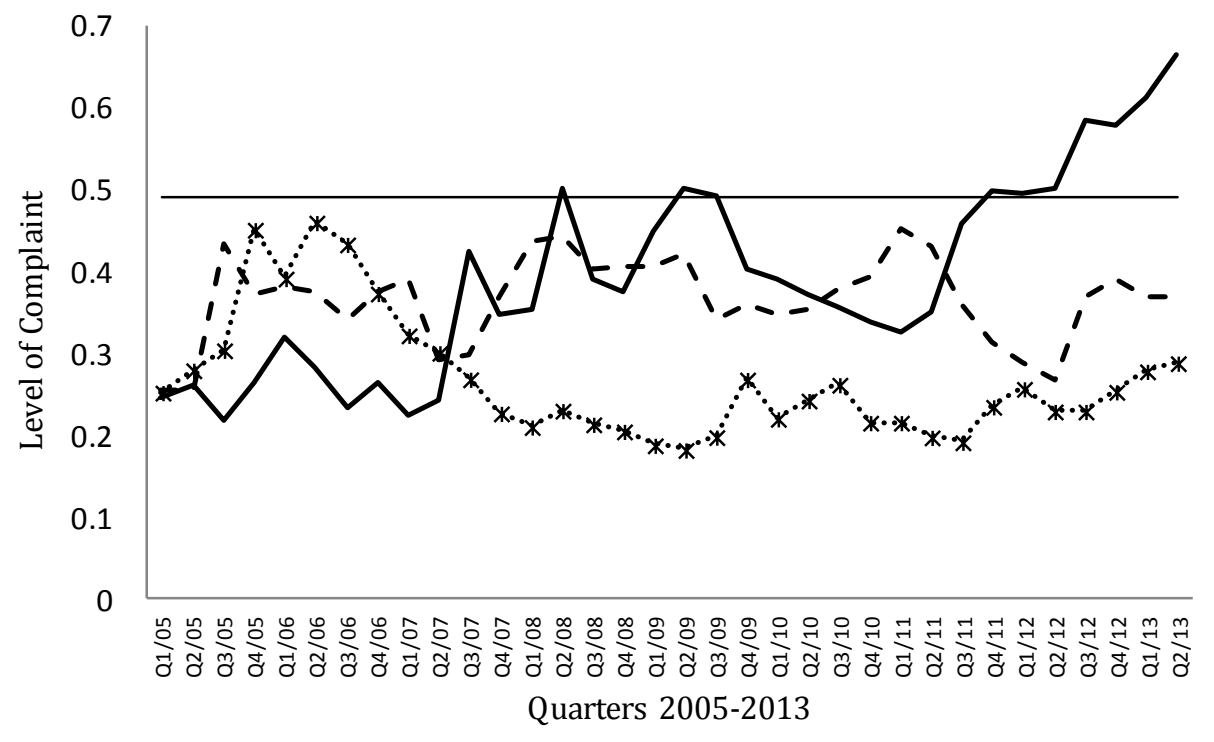

Figure 3. Level of Negative Word of Mouth and the Estimated Optimal Level. 


\section{Final Considerations and Implications}

The aim of this study is to test a non-linear effect of complaint on company market value. The results support the posited hypothesis, with relevant implications for marketing practitioners as well as researchers. Previous studies in marketing showed that complaint affects marketing program effectiveness (e.g. Cronin \& Fox, 2010; Tax, Brown, \& Chandrashekaran, 1998). Our study contributes to this stream of research by providing a negative $v s$. positive tradeoff rationale and empirical evidence that it can be productive to reduce the complaint level to certain break point level. The monitoring complaint levels become very important to the process of planning and executing marketing programs and meeting budgets requirements.

Previous studies have shown that poor complaint management has a detrimental effect on customer satisfaction (Bitner, Booms, \& Tetreault, 1990; Dixon et al., 2010). Our study contributes to the understanding of the mechanisms that allow companies to weigh the pros and cons of reducing complaints filed with a public agency to a very low level. The evidence shown in this paper suggests that companies can tolerate a certain level of complaint with no loss in market value. It is critical to allocate resources to keep the level of complaints close to the break point so that the spread of negative information has no affect on performance. This is the opposite of what managers tend to do: managers use complaint rates as an indicator for consumer satisfaction and assume that if rates are very low, overall market value increases. Our findings provide important guidance for marketing practitioners especially in relation to the process of planning, controlling and executing marketing activities in a context of a highly competitive and relatively homogeneous value proposition.

The managerial implications of our study fall into two main issues. First, measuring and monitoring the number of complaints are critical tasks for marketing departments, especially regarding complaints made to third parties, such as regulatory agencies. Closely assessing the level of such potential negative word of mouth and making an effort to handle consumer response may increase loyalty and customer satisfaction after a successful failure recovery (Santos \& Fernandes, 2008; Webster \& Sundaram, 1998). Our results indicate the existence of a break point: trying to reduce complaints to very low levels will negatively affect a company's market value, due to low detrimental image exposure and excessive handling costs that are not offset by the positive cash flow generated. However, letting the level of complaints grow beyond the break point will negatively impact a company's market value. This requires managers to make an effort to reduce the number of complaints. It thus becomes important for every company, in the light of their specific contextual conditions, to use and improve this model based on the best information and data available.

A second managerial issue is related to the uncontrollable dynamics of social networks. It is hard to control everything that is said about products and services, particularly, in terms of online communication. There is a daily need for marketing departments to monitor blogs, social communities, and public and private complaint channels. Such monitoring will help managers identify opportunities and important duties related to managing customer satisfaction level and reduce the dissemination of negative viral information about the company's offerings (Godes \& Mayzlin, 2004).

Our research has some limitations and offers indications for future research. The results may be generalized with caution due to the particular market characteristics of the cell phone industry in Brazil as well as the period examined. Further studies can focus on other sectors, countries and periods. We assumed a continuous U-shape function that one may think that the increase in the number of complaints is a proxy for the increase in company value. This discontinuous effect of complaint should receive attention in future non-linear research. Our rationale of positive and negative tradeoffs may take different mechanisms in different contexts. Future studies may look at other consumer and company issues to deepen the understanding of complaint effects. Future studies may also look into the content of such complaints. It would be of interest to qualify the different type of complaints that exist by source, cause, intensity and offer type, among others. Based on Bitner, Booms and Tetreault (1990) it would be valid, if data is available, to segregate the different types of 
complaints and their respective impacts on company market value. Following up on this theme, there is a need to qualify complaints in relation to consumers' emotions and behavior. According to Sjödin (2008), anger is the negative emotion that leads consumers to engage in negative word of mouth, which is detrimental to the process of creating brand and company value. Future studies combining behavioral psychology and marketing can further complement this work by identifying which specific types of mechanisms underlie these negative emotions (McColl-Kennedy et al., 2011; Romani et al., 2012).

\section{References}

Anderson, E. W. (1998). Customer satisfaction and word of mouth. Journal of Service Research, 1(1), 5-17. doi: 10.1177/109467059800100102

Anderson, E. W., Fornell, C., \& Mazvancheryl, S. K. (2004). Customer satisfaction and shareholder value. Journal of Marketing, 68(4), 172-185. doi: 10.1509/jmkg.68.4.172.42723

Anderson, E. W., Fornell, C., \& Rust, R. T. (1997). Customer satisfaction, productivity, and profitability: differences between goods and services. Marketing Science, 16(2), 129-145. doi: 10.1287/mksc.16.2.129

Andreassen, T. W., \& Lindestad, B. (1998). The effect of corporate image in the formation of customer loyalty. Journal of Service Research, 1(1), 82-92. doi: 10.1177/109467059800100107

Bentivegna, F. J. (2002). Fatores de impacto no sucesso do marketing boca a boca online. Revista de Administração de Empresas, 42(1), 79-87.

Berger, P. D., Eechambadi, N., George, M., Lehmann, D. R., Rizley, R., \& Venkatesan, R. (2006). From customer lifetime value to shareholder value: theory, empirical evidence, and issues for future research. Journal of Service Research, 9(2), 156-167. doi: 10.1177/1094670506293569

Berger, P. G., \& Ofek, E. (1995). Diversification's effect on firm value. Journal of Financial Economics, 37(1), 39-65. doi: 10.1016/0304-405X(94)00798-6

Bernhardt, K. L., Donthu, N., \& Kennett, P. A. (2000). A longitudinal analysis of satisfaction and profitability. Journal of Business Research, 47(2), 161-171. doi: 10.1016/S0148-2963(98)00042-3

Bitner, M. J., Booms, B. H., \& Tetreault, M. S. (1990). The service encounter: diagnosing favorable and unfavorable incidents. Journal of Marketing, 54(1), 71-84.

Brown, J. J., \& Reingen, P. (1987). Social ties and word-of-mouth referral behavior. Journal of Consumer Research, 14(3), 350-362.

Brown, S. W., Webster, F. E., Jr., Steenkamp, J.-B. E. M., Wilkie, W. L., Sheth, J. N., Sisodia, R., S., Kerin, R. A., MacInnis, D., McAlister, L., Raju, J. S., et al. (2005). Marketing renaissance: opportunities and imperatives for improving marketing thought, practice, and infrastructure. Journal of Marketing, 69(4), 1-25. doi: 10.1509/jmkg.2005.69.4.1

Chakravarthy, B. S. (1986). Measuring strategic performance. Strategic Management Journal, 7(5), 437-458. doi: $10.1002 / \mathrm{smj} .4250070505$

Chevalier, J. A., \& Mayzlin, D. (2006). The effect of word of mouth on sales: online book reviews. Journal of Marketing Research, 43(3), 345-354. doi: 10.1509/jmkr.43.3.345

Chung, K. H., \& Pruitt, S. W. (1994). A simple approximation of Tobin's Q. Financial Management, 23(3), 70-74. 
Cronin, J. J., \& Fox, G. L. (2010). The implications of third-party customer complaining for advertising efforts. Journal of Advertising, 39(2), 21-34. doi: 10.2753/JOA0091-3367390202

De Bruyn, A., \& Lilien, G. L. (2008). A multi-stage model of word-of-mouth influence through viral marketing. International Journal of Research in Marketing, 25(3), 151-163. doi: 10.1016/j.ijresmar.2008.03.004

Dichter, E. (1966). How word-of-mouth advertising works. Harvard Business Review, 44(6), 147-166.

Dixon, M., Freeman, K., \& Toman, N. (2010). Stop trying to delight your customers. Harvard Business Review, 88(7/8), 116-122.

East, R., Hammond, K., \& Lomax, W. (2008). Measuring the impact of positive and negative word of mouth on brand purchase probability. International Journal of Research in Marketing, 25(3), 215-224. doi: 10.1016/j.jiresmar.2008.04.001

Fama, E. F. (1970). Efficient capital markets: a review of theory and empirical work. The Journal of Finance, 25(2), 383-417. doi: 10.1111/j.1540-6261.1970.tb00518.x

Fang, E., Palmatier, R. W., \& Steenkamp, J.-B. E. M. (2008). Effect of service transition strategies on firm value. Journal of Marketing, 72(5) 1-14. doi: 10.1509/jmkg.72.5.1

Feick, L. F. (1987). Latent class models for the analysis of behavioral hierarchies. Journal of Marketing Research, 24(2), 174-186. doi: 10.2307/3151507

Fleury, A., \& Fleury, M. T. (2003). The evolution of strategies and organizational competencies in the telecommunications industry. International Journal of Information Technology \& Decision Making, 2(4), 577-596. doi: 10.1142/S021962200300080X

Fornell, C., \& Wernerfelt, B. (1988). A model for customer complaint management. Marketing Science, 7(3), 287-298.

Fornell, C., Mithas, S., Morgeson, F. V., III, \& Krishnan, M. S. (2006). Customer satisfaction and stock prices: high returns, low risk. Journal of Marketing, 70(1), 3-14. doi: 10.1509/jmkg.2006.70.1.3

Godes, D., \& Mayzlin, D. (2004). Using online conversations to study word-of-mouth communication. Marketing Science, 23(4), 545-560.

Goldenberg, J., Han, S., Lehmann, D. R., \& Hong, J. W. (2009). The role of hubs in the adoption processes. Journal of Marketing, 73(2), 1-13. doi: 10.1509/jmkg.73.2.1

Goldenberg, J., Libai, B., Moldovan, S., \& Muller, E. (2007). The NPV of bad news. International Journal of Research in Marketing, 24(3), 186-200. doi: 10.1016/j.ijresmar.2007.02.003

Grönroos, C. (1984). A service quality model and its marketing implications. European Journal of Marketing, 18(4), 36-44. doi: 10.1108/EUM0000000004784

Gruca, T. S., \& Rego, L. L. (2005). Customer satisfaction, cash flow, and shareholder value. Journal of Marketing, 69(3), 115-130. doi: 10.1509/jmkg.69.3.1.66358

Gujarati, D. N. (2003). Basic econometrics (4th ed.). New York: McGraw-Hill.

Gupta, S., Lehmann, D. R., \& Stuart, J. A. (2004). Valuing customers. Journal of Marketing Research, 4l(1), 7-18. doi: 10.1509/jmkr.41.1.7.25084

Harris, L. C., \& Ogbonna, E. (2013). Forms of employee negative word-of-mouth: a study of frontline workers. Employee Relations, 35(1), 39-60. doi: 10.1108/01425451311279401 
Heskett, J. L., Jones, T. O., Loveman, G. W., Sasser, W. E., Jr., \& Schlesinger, L. A. (1994). Putting the service-profit chain to work. Harvard Business Review, 72(2), 164-170.

Kozinets, R. V., Valck, K. de, Wojnick, A. C., \& Wilner, S. J. S. (2010). Networked narratives: understanding word-of-mouth marketing in online communities. Journal of Marketing, 74(2), 71-89. doi: $10.1509 / j m k g .74 .2 .71$

Laer, T. van, \& Ruyter, K. de (2012). In stories we trust: how narrative apologies provide cover for competitive vulnerability after integrity-violating blog posts. International Journal of Research in Marketing, 27(2), 164-174. doi: 10.1016/j.ijresmar.2009.12.010

Lee, R. P., \& Grewal, R. (2004). Strategic responses to new technologies and their impact on firm performance. Journal of Marketing, 68(4), 157-171. doi: 10.1509/jmkg.68.4.157.42730

Lee, R., \& Romaniuk, J. (2009). Relating switching costs to positive and negative word-of-mouth. Journal of Consumer Satisfaction, Dissatisfaction and Complaining Behavior, 22, 54-67.

Lehmann, D. R. (2004). Metrics for making marketing matter. Journal of Marketing, 68(4), 73-75. doi: $10.1509 / \mathrm{jmkg} \cdot 68.4 .73 .42727$

Luo, X. (2007). Consumer negative voice and firm- idiosyncratic stock returns. Journal of Marketing, 71(3), 75-88. doi: 10.1509/jmkg.71.3.75

Luo, X. (2009). Quantifying the long-term impact of negative word of mouth on cash flows and stock prices. Marketing Science, 28(1), 148-165. doi: 10.1287/mksc.1080.0389

Luo, X., \& Homburg, C. (2008). Satisfaction, complaint, and the stock value gap. Journal of Marketing, 72(4), 29-43. doi: 10.1509/jmkg.72.4.29

Matos, C. A. de, \& Rossi, C. A. V. (2008). Word-of-mouth communications in marketing: a metaanalytic review of the antecedents and moderators. Journal of the Academy of Marketing Science, 36(4), 578-596.

Matos, C. A. de, \& Veiga, R. T. (2005). How to deal with negative publicity: the importance of consumer involvement. Brazilian Administration Review, 2(1), 57-72. Retrieved from http://www.scielo.br/pdf/bar/v2n1/v2n1a05.pdf. doi: 10.1590/S1807-76922005000100005

McColl-Kennedy, J. R., Sparks, B. A., \& Nguyen, D. T. (2011). Customer's angry voice: targeting employees or the organization? Journal of Business Research, 64(7), 707-713. doi: 10.1016/j.jbusres.2010.08.004

Mintz, O., \& Currim, I. S. (2013). What drives managerial use of marketing and financial metrics and does metric use affect performance of marketing-mix activities? Journal of Marketing, 77(2), 17-40. doi: 10.1509/jm.11.0463

Mittal, V., Ross, W. T., Jr., \& Baldasare, P. M. (1998). The asymmetric impact of negative and positive attribute-level performance on overall satisfaction and repurchase intentions. Journal of Marketing, 62(1), 33-47.

Niraj, R., Gupta, M., \& Narasimhan, C. (2001). Customer profitability in a supply chain. Journal of Marketing, 65(3), 1-16. doi: 10.1509/jmkg.65.3.1.18332

Osinga, E. C., Leeflang, P. S. H., Srinivasan, S., \& Wieringa, J. E. (2011). Why do firms invest in consumer advertising with limited sales response? A shareholder perspective. Journal of Marketing, 75(1), 109-124. doi: 10.1509/jmkg.75.1.109

Richins, M. L. (1983). Negative word-of-mouth by dissatisfied consumers: a pilot study. Journal of Marketing, 47(1), 68-78. 
Romani, S., Grappi, S., \& Dalli, D. (2012). Emotions that drive consumers away from brands: measuring negative emotions toward brands and their behavioral effects. International Journal of Research in Marketing, 29(1), 55-67. doi: 10.1016/j.ijresmar.2011.07.001

Rust, R. T., Lemon, K. N., \& Zeithaml, V. A. (2004). Return on marketing: using customer equity to focus marketing strategy. Journal of Marketing, 68(1), 109-127. doi: 10.1509/jmkg.68.1.109.24030

Ruyter, K. de, \& Brack, A. (1993). European legal developments in product safety and liability: the role of customer complaint management as a defensive marketing tool. International Journal of Research in Marketing, 10(2), 153-164. doi: 10.1016/0167-8116(93)90002-G

Santos, C. P. dos, \& Fernandes, D. V. D. H. (2008). Antecedents and consequences of consumer trust in the context of service recovery. Brazilian Administration Review, 5(3), 225-244. Retrieved from http://www.scielo.br/pdf/bar/v5n3/v5n3a05.pdf. doi: 10.1590/S1807-76922008000300005

Santos, C. P. dos, \& Fernandes, D. V. D. H. (2011). Perceptions of justice after recovery efforts in internet purchasing: the impact on consumer trust and loyalty toward retailing sites and online shopping in general. Brazilian Administration Review, 8(3), 225-246. Retrieved from http://www.scielo.br/pdf/bar/v8n3/a02v8n3.pdf. doi: 10.1590/S1807-76922011000300002

Shaver, J. M. (1998). Accounting for endogeneity when assessing strategy perfomance: does entry mode choice affect FDI survival? Management Science, 44(4), 571-585.

Simon, C. J., \& Sullivan, M. W. (1993). The measurement and determinants of brand equity: a financial approach. Marketing Science, 12(1), 28-52.

Singh, J. (1988). Consumer complaint intentions and behavior: definitional and taxonomical issues. Journal of Marketing, 52(1), 93-107.

Singh, J., \& Wilkes, R. E. (1996). When consumers complain: a path analysis of the key antecedents of consumer complaint response estimates. Journal of the Academy of Marketing Science, 24(4), 350-365.

Sjödin, H. (2008). Upsetting brand extensions: an enquiry into current customers' inclination to spread negative word of mouth. Journal of Brand Management, 15(4), 258-271.

Skinner, W. (1969). Manufacturing - missing link in corporate strategy. Harvard Business Review, 47(3), 136-145.

Smith, K. T., Smith, M., \& Wang, K. (2010). Does brand management of corporate reputation translate into higher market value? Journal of Strategic Marketing, 18(3), 201-221. doi: $10.1080 / 09652540903537030$

Sorescu, A. B., \& Spanjol, J. (2008). Innovation's effect on firm value and risk: insights from consumer packaged goods. Journal of Marketing, 72(2), 114-132. doi: 10.1509/jmkg.72.2.114

Srinivasan, S., \& Hanssens, D. M. (2009). Marketing and firm value: metrics, methods, findings, and future directions. Journal of Marketing Research, 46(3), 293-312. doi: 10.1509/jmkr.46.3.293

Srivastava, R. K., Shervani, T. A., \& Fahey, L. (1998). Market-based assets and shareholder value: a framework for analysis. Journal of Marketing, 62(1), 2-18.

Tax, S. S., Brown, S. W., \& Chandrashekaran, M. (1998). Customer evaluations of service complaint experiences: implications for relationship marketing. Journal of Marketing, 62(2), 60-76.

Torres, A., \& Tribó, J. A. (2011). Customer satisfaction and brand equity. Journal of Business Research, 64(10), 1089-1096. 
Trusov, M., Bucklin, R. E., \& Pauwels, K. (2009). Effects of word-of-mouth versus traditional marketing: findings from an internet social networking site. Journal of Marketing, 73(5), 90102. doi: $10.1509 / j m k g .73 .5 .90$

Venkatesan, R., \& Kumar, V. (2004). A customer lifetime value framework for customer selection and resource allocation strategy. Journal of Marketing, 68(4), 106-125. doi: 10.1509/jmkg.68.4.106.42728

Ward, J. C., \& Ostrom, A. L. (2006). Complaining to the masses: the role of protest framing in customer-created complaint web sites. Journal of Consumer Research, 33(2), 220-230. doi: $10.1086 / 506303$

Webster, C., \& Sundaram, D. S. (1998). Service consumption criticality in failure recovery. Journal of Business Research, 41(2), 153-159. doi: 10.1016/S0148-2963(97)00004-0

Weimann, G. (1991). The influentials: back to the concept of opinion leaders? Public Opinions Quarterly, 55(2), 267-279. doi: 10.1086/269257

Winchester, M., Romaniuk, J., \& Bogomolova, S. (2008). Positive and negative brand beliefs and brand defection/uptake. European Journal of Marketing, 42(5/6), 553-570. doi: $10.1108 / 03090560810862507$ 